\title{
MAURICE ALLAIS O PODEJMOWANIU DECYZJI
}

\author{
Leszek Jerzy Jasiński \\ Politechnika Warszawska
}

\section{Marcin Malawski \\ Akademia Leona Koźmińskiego i Instytut Podstaw Informatyki PAN}

Na gruncie teorii proces podejmowania decyzji jest rozpatrywany z dwóch punktów widzenia. W pierwszym przypadku szuka się metod dochodzenia do rozstrzygnięć optymalnych, czyli najlepszych. Zakłada się, że decydent działa racjonalnie, potrafi prowadzić złożone obliczenia oraz dysponuje niezbędną do tego informacją. W drugim przypadku opisuje się, jak decyzje faktycznie zapadają. Bada się, jak bardzo ich wybór jest racjonalny, a gdy okazuje się od tego daleki, jakie okoliczności na nim ważą. W perspektywie czysto pragmatycznej drugie podejście przynosi zalecenia pozwalające unikać błędów w procesach decyzyjnych. Zadaje się pytanie, czy należy zawsze zmierzać do znalezienia postanowień optymalnych. Czasami rozwiązania suboptymalne, to znaczy bliskie trudnym do wskazania rozwiązaniom najlepszym, okazują się satysfakcjonujące. W teorii podejmowania decyzji występują zatem podejścia normatywne i deskryptywne.

Maurice Allais (1911-2010), wybitny francuski ekonomista i fizyk, wzbogacił deskryptywną teorię decyzji. Jako fizyk stał się znany najbardziej jako odkrywca tak zwanego efektu Allaisa ${ }^{1}$. Wykazał on, że anomalna oscylacja wahadła podczas zaćmienia Słońca nie może zostać wyjaśniona za pomocą standardowych modeli grawitacji. Jako ekonomista i przedstawiciel teorii zarządzania podejmował różne zagadnienia i jest kwestią otwartą, czy wkład do deskryptywnej teorii decyzji stanowi w jego dorobku pozycję najważniejszą.

Interesowało go wiele zagadnień, może najbardziej kwestie ogólnej równowagi w gospodarce. W 1988 roku otrzymał ekonomiczną Nagrodę Nobla za - przytoczmy wypowiedzianą przy tej okazji sentencję uzasadniającą wyróżnienie - „pionierski wkład do teorii rynków i problematyki efektywnego wykorzystania zasobów". Spośród różnych osiągnięć Allaisa Królewska Szwedzka Akademia Nauk wyeksponowała

1 Występowanie tego efektu do dziś jest sporne - nie zostało jednoznacznie potwierdzone w późniejszych badaniach. Jeśli nawet „anomalia Allais” nie jest po prostu skutkiem błędu pomiaru w jego eksperymencie, jest ona efektem bardzo małej skali, trudnym do stwierdzenia zwłaszcza wobec rzadkości i krótkiego trwania zaćmień Słońca. 
zatem wyniki inne niż tematyka decyzyjna. Tym pozostałym osiągnięciom poświęcimy dalej nieco uwagi. Najważniejsze będą jednak dla nas konstatacje związane z teorią decyzji. Allais okazał się jednym z twórców głośnej dzisiaj ekonomii behawioralnej.

Stanowi ona alternatywę dla dominującego od XIX wieku do początków XXI wieku nurtu w myśli ekonomicznej wywodzącego się z powstałej w XVIII wieku ekonomii klasycznej, która przerodziła się w tak zwaną ekonomię neoklasyczną, a później w neoklasyczne uwarunkowanie licznych, czasem rozbieżnych nurtów w analizie ekonomicznej. Na czym polega różnica między, w istocie wykluczającymi się, ujęciami badawczymi: ekonomią pozostającą w cieniu podejścia neoklasycznego i ekonomią behawioralną?

Budując teorie ekonomiczne, wygodnie jest założyć, że w gospodarce w roli producenta i konsumenta działa homo oeconomicus (człowiek ekonomiczny). Wszystkie podmioty gospodarcze, czyli przedsiębiorstwa i gospodarstwa domowe, sektor publiczny i otoczenie międzynarodowe danego układu gospodarczego, mają postępować w pełni racjonalnie. W sposób racjonalny chcą i potrafią reagować na bodźce zewnętrzne oraz podejmować najlepsze decyzje. Co więcej, homo oeconomicus potrafi w pełni wykorzystać wszelką dostępną mu informację, o ile tylko jest ona istotna dla wyboru jego decyzji. Jest także podmiotem egoistycznym, a w każdym razie nakierowanym na realizację własnych interesów (MacCrimmon, 1968). To one i tylko one budują kryterium wyboru jego decyzji.

Podejście neoklasyczne eksponuje efektywność działań ekonomicznych. Jest to jego motyw przewodni, obecny w nim na stałe. Uczynienie punktem wyjścia rozumowania trzech założeń - podmioty ekonomiczne są całkowicie racjonalne, są zainteresowane wyłącznie korzyściami osobistymi i umieją optymalnie korzystać z posiadanych informacji - jest dla budowy teorii bardzo dogodne. Ekonomia nie jest nauką dedukcyjną, ale w jej ramach przeprowadza się wielokrotnie rozumowanie dedukcyjne. Przyjęcie trzech niewątpliwie upraszczających założeń znakomicie służy budowie zwartej teorii. Bez tego jest dużo trudniej wskazywać prawidłowości rządzące życiem gospodarczym.

Niemała część ekonomistów zaczęła traktować te trzy założenia jako rzeczywistość, a nie jako udogodnienie badawcze. Spotkało się to ze sprzeciwem.

Założenie o istnieniu homo oeconomicus krytykuje ekonomia behawioralna (psychoekonomia) (Teitelbaum i Zeiler (red.), 2018). Podkreśla ona wpływ czynników emocjonalnych i innych elementów pozaracjonalnych na decyzje podmiotów gospodarczych. Motywacja decydentów - np. menedżerów czy konsumentów - bywa rozmaita. Ludzie nie zawsze są jednoznacznie interesowni, nawet gdy takie nastawienie w sobie wykształcą. Za zmienny oraz niemożliwy do odgadnięcia ekonomia behawio- 
ralna uznaje stan rynków. Również wiedza o tym, co się na nich dzieje, jest zwykle niekompletna. Podejmujący decyzję często nie potrafi dokonać optymalizacji jej wyboru, nierzadko brakuje mu na to czasu i ochoty. Zanegowanie hipotezy homo oeconomicus jest punktem wyjścia licznych teorii ekonomicznych niemieszczących się w tak zwanym głównym nurcie, nie tylko ekonomii behawioralnej i psychologicznej.

Założenie o nieograniczonej racjonalności podmiotów ekonomicznych pojawiło się w pracach Johna Stuarta Milla (1806-1873). W XIX wieku krytykował je John Neville Keynes (1852-1949), ojciec jednego z najważniejszych ekonomistów XX wieku Johna Maynarda Keynesa (1883-1946). Jednak to Mill, a nie Keynes ojciec, wytyczył drogi rozwoju ekonomii w tym punkcie. Długa jest lista ekonomistów i przedstawicieli innych dyscyplin naukowych, którzy przyczynili się do rozwoju ekonomii psychologicznej w różnych jej wymiarach (są na niej także laureaci ekonomicznej Nagrody Nobla). Wymieńmy najważniejszych z nich, jak Kenneth J. Arrow (1921-2017), Daniel Kahneman, Hyman Minsky (1919-1996), John Quiggin, Robert J. Shiller, Herbert A. Simon (1916-2001), Richard Thaler, Amos Tversky (1937-1996) oraz, last but not least, Maurice Allais (Jasiński, 2021). Częścią ekonomii psychologicznej są intensywnie rozwijane od wielu lat finanse behawioralne.

Dorobek francuskiego ekonomisty w zakresie podejmowania decyzji polega na sformułowaniu sławnego paradoksu Allais. Obrazuje on procesy wyboru dokonywanego przez dowolny podmiot ekonomiczny. Najwygodniej jest uznać, że podmiotem tym jest konsument.

W analizie pojawia się funkcja użyteczności: odwzorowanie zestawów dóbr ekonomicznych w zbiór liczb. Zapewnia ona, mówiąc prostym językiem, liczbowy pomiar wartości, przydatności i stopnia zainteresowania posiadaniem określonych przedmiotów fizycznych lub aktywów finansowych. W ogólnym przypadku jest to funkcja wielu zmiennych, która dla dowolnej wiązki towarowej (czyli koszyka dóbr) wyznacza „użyteczność” tej wiązki dla konsumenta. Zazwyczaj zakłada się pewne jej własności matematyczne, np. to, że im więcej, ceteris paribus, danego dobra, tym większa użyteczność wiązki, a także, że takie samo powiększenie koszyka dóbr bardziej zwiększa użyteczność w sytuacji, gdy przedtem koszyk był mały, niż gdy był większy (dodatkowe 500 zł jest dla nas warte więcej, gdy mamy w tej chwili 2000 zł, niż gdybyśmy mieli 200 tysięcy). Oznacza to, że użyteczność jest rosnącą i wklęsłą funkcją każdej zmiennej (ilości każdego z dóbr). Mówiąc inaczej, funkcja użyteczności w postaci standardowej - nie wyklucza się wprowadzania postaci innych, wyjątkowych - ilustruje rosnące coraz wolniej, przynajmniej do pewnego momentu, zadowolenie podmiotu ekonomicznego z dysponowania coraz większą ilością dóbr (a w niektórych przypadkach także istnienie ich zestawu przynoszącego maksymalną satysfakcję). 
Funkcja użyteczności, pomimo opisanych cech ogólnych, ma charakter subiektywny, w małym stopniu uniwersalny. Jej szczegółowy przebieg zależy od preferencji konkretnego podmiotu i - co równie ważne - od jego skłonności do akceptacji ryzyka.

Tam, gdzie wynik działań ekonomicznych jest niejednoznaczny, gdzie mogą one różnie się zakończyć, konstruuje się oczekiwaną użyteczność. W takich warunkach ocena nie może być jednolita, gdyż nie wiadomo, co się wydarzy. Posługujemy się odmianą wartości oczekiwanej, która jest podstawowym pojęciem rachunku prawdopodobieństwa. Do wyznaczenia tej charakterystyki potrzeba liczbowych pomiarów użyteczności poszczególnych wariantów sytuacji i prawdopodobieństw ich wystąpienia. Oczekiwana użyteczność jest sumą iloczynów użyteczności możliwych wariantów i prawdopodobieństw tych wariantów. Jest to więc spodziewana średnia użyteczność, która ujawniłaby się, gdyby proces decyzyjny był powtarzany wiele razy.

Jak należy wybierać optymalną decyzję? Co proponuje normatywne podejście w teorii decyzji? Jak zachowa się homo oeconomicus? Należy sięgać po decyzję maksymalizującą funkcję użyteczności. W sytuacji, gdy efekty rozważanych działań są niejednoznaczne, powinno się wybierać rozstrzygnięcie, któremu odpowiada największa oczekiwana użyteczność (Tyszka i Zaleśkiewicz, 2001, s. 72).

Czas zakończyć porządkowanie aparatury pojęciowej i przejść do paradoksu Allais. Celem tego badacza było podważenie praktycznej przydatności teorii użyteczności i wynikającej z niej teorii użyteczności krańcowej. Aby tego dokonać, w 1953 roku przeprowadził bardzo prosty eksperyment (Allais, 1953), sprowadzający się do dwóch wyborów spośród dwóch loterii. Pozwoliło to ustalić, jak zazwyczaj ludzie reagują, stojąc przed takim rozstrzygnięciem w praktyce.

„Koszyki dóbr” w tym eksperymencie składały się z jednego dobra - po prostu pieniędzy. Natomiast decyzja była podejmowana w warunkach ryzyka: decydent miał dwukrotnie stwierdzić, którą z loterii z pieniężnymi wypłatami wybrałby dla siebie z podanego mu zestawu. W pierwszej części eksperymentu do wyboru były: stuprocentowo pewna wypłata pół miliona dolarów (wybranie jej to decyzja A) lub loteria podana w tabeli 1 poniżej (jej wybór to decyzja B) (Tyszka, 2010, s. 200; na podstawie tego źródła powstały wszystkie trzy zamieszczone w artykule tabele). Podejmując decyzję B, pan Kowalski otrzyma dwa i pół miliona dolarów, pół miliona lub nie zyska niczego. Prawdopodobieństwo każdej z tych wygranych jest podane obok jej wielkości w tabeli 1.

Warto zauważyć, że oczekiwana wygrana na loterii B jest wyższa niż na „loterii” A:

$$
0,1 * 2500000+0,89 * 500000+0,01 * 0=695000>500000
$$

Nie oznacza to jednak wcale, że decydent wybierający decyzję A zamiast B jest nieracjonalny. Taki wybór jest jak najbardziej zgodny z maksymalizacją oczekiwanej 
użyteczności, jeśli tylko jego funkcja użyteczności - oznaczmy ją przez $u$ - spełnia nierówność:

$$
\mathrm{E} u(\mathrm{~A})=u\left(5 * 10^{5}\right)>0,1 * u\left(25 * 10^{5}\right)+0,89 * u\left(5 * 10^{5}\right)+0,01 * u(0)=\mathrm{E} u(\mathrm{~B})
$$

Tabela 1

Sytuacja decyzyjna 1

\begin{tabular}{cc}
\hline Decyzja $\mathbf{A}$ & Decyzja B \\
\hline \multirow{3}{*}{$0,5 \mathrm{~m} \ln$ \$ na pewno } & $2,5 \mathrm{~m} \ln$ \$ z prawdopodobieństwem 0,10 \\
\cline { 2 - 2 } & $0,5 \mathrm{~m} \ln$ \$ z prawdopodobieństwem 0,89 \\
\cline { 2 - 2 } & 0 \$ z prawdopodobieństwem 0,01 \\
\hline
\end{tabular}

Co więcej, Maurice Allais przekonywał, że przeciętny człowiek wybierze decyzję A. Daje mu ona pewność bardzo dużej wygranej, chociaż wśród wszystkich widocznych w tabeli 1 nie jest to kwota największa. Decyzja B kusi wprawdzie wygraną o wiele wyższą $(2,5 \mathrm{mln} \$)$, ale jest ona raczej mało prawdopodobna. Wybierając B, najprawdopodobniej wygra się tyle samo, co na "loterii” A, ale nie jest to pewne, natomiast możliwy - choć bardzo mało prawdopodobny - jest wynik zdecydowanie najgorszy, czyli wyjście z pustymi rękami. Decydent, który wysoko ceni sobie wygranie pół miliona i bardzo chce uniknąć najgorszego wyniku, wybierze decyzję A nie oglądając się na możliwość jeszcze większej wygranej w razie wybrania B; dodatkowo może go w tym utwierdzać awersja do mechanizmu losowego. I rzeczywiście tacy decydenci są w większości: wybór decyzji A deklaruje też znaczna większość ludzi przebadanych w licznych powtórzeniach eksperymentu Allais. Jeżeli rzeczywiście maksymalizują oni swą oczekiwaną użyteczność, to ich funkcje użyteczności spełniają nierówność (1).

W drugiej części eksperymentu decydent ma do dyspozycji alternatywę sprowadzającą się do wyboru między dwiema loteriami (wcześniej loteria była przeciwstawiona loterii „zdegenerowanej”, czyli rozstrzygnięciu wolnemu od niepewności). Dwie nowe loterie, związane z wyborem decyzji C albo D, opisano w tabeli 2.

Tablica 2

Sytuacja decyzyjna 2

\begin{tabular}{cc}
\hline Decyzja C & Decyzja D \\
\hline $0,5 \mathrm{~m} \ln \$$ z prawdopodobieństwem 0,11 & $2,5 \mathrm{~m} \ln \$$ z prawdopodobieństwem 0,1 \\
\hline 0 z prawdopodobieństwem 0,89 & 0 z prawdopodobieństwem 0,90 \\
\hline
\end{tabular}

W tym przypadku duża większość badanych deklaruje wybór decyzji D. Jest to zgodne z potocznym zdrowym rozsądkiem. Na obu loteriach wygrana jest niepewna, 
jej prawdopodobieństwa różnią się między sobą nieznacznie, a za to sama kwota wygrywana na loterii B jest pięciokrotnie wyższa. Trudno więc dziwić się, że mając taki wybór, ludzie na ogół wybierają loterię z wyższą oczekiwaną wypłatą (C: 55 000, D: 250 000). Decydent maksymalizujący swą oczekiwaną użyteczność wybierze D zamiast $\mathrm{C}$, jeżeli jego funkcja użyteczności $u$ spełnia nierówność:

$$
\mathrm{E} u(\mathrm{D})=0,1 * u\left(25 * 10^{5}\right)+0,9 * u(0)>0,11 * u\left(5 * 10^{5}\right)+0,89 * u(0)=\mathrm{E} u(\mathrm{C})
$$

Ponadto w rzeczywistości, gdy ludziom zada się pytanie o wybory w obu tych sytuacjach decyzyjnych, najczęściej wybieraną parą jest decyzja A w pierwszym problemie i decyzja D w drugim. Takie wybory decydenta oznaczają jednak, że nie maksymalizuje on oczekiwanej użyteczności: jeśli racjonalny decydent wybiera A w pierwszej parze, to nie może wybierać D w drugiej, gdyż, jak łatwo sprawdzić, nierówności (1) i (2) są sprzeczne.

Ta sprzeczność jest szczególnie dobrze widoczna, gdy zamiast podawać prawdopodobieństwa, przedstawi się każdą z czterech decyzji w postaci loterii z ponumerowanymi biletami. Biletów na każdą loterię jest 100 i każdy może zostać wylosowany z tym samym prawdopodobieństwem (tabela 3). Takie przedstawienie zaproponował Leonard J. Savage (1917-1971), wybitny statystyk i jeden z pionierów normatywnej teorii podejmowania decyzji w warunkach niepewności, który był także jednym z pierwszych czytelników pracy Allaisa (Savage, 1954) i początkowo też wybrał decyzje A i D, ale - jak twierdził - po zastanowieniu zmienił swoje preferencje na zgodne z teorią oczekiwanej użyteczności.

Tabela 3

Analiza Allaisa przedstawiona przez Savage'a

\begin{tabular}{ccccc}
\hline \multirow{2}{*}{ Sytuacja } & \multirow{2}{*}{ Decyzja } & \multicolumn{3}{c}{ Numer biletu } \\
\cline { 3 - 5 } & & 1 & $2-11$ & $12-100$ \\
\hline \multirow{2}{*}{ Sytuacja 1 } & decyzja A & $0,5 \mathrm{mln}$ & $0,5 \mathrm{mln}$ & $0,5 \mathrm{mln}$ \\
\cline { 2 - 5 } & decyzja B & 0 & $2,5 \mathrm{mln}$ & $0,5 \mathrm{mln}$ \\
\hline \multirow{2}{*}{ Sytuacja 2 } & decyzja C & $0,5 \mathrm{mln}$ & $0,5 \mathrm{mln}$ & 0 \\
\cline { 2 - 5 } & decyzja D & 0 & $2,5 \mathrm{mln}$ & 0 \\
\hline
\end{tabular}

Jak widać, decyzje A i B dają różne wyniki tylko w przypadku wylosowania któregoś z biletów o numerach od 1 do 11 i to samo dotyczy decyzji $C$ i $\mathrm{D}$. W takim przypadku jednak decyzja A daje ten sam wynik co $C$, a B - ten sam co D. Jeśli więc racjonalny decydent woli A od B, to woli też $\mathrm{C}$ od D i odwrotnie. Zrozumienie tego nie wymaga znajomości teorii oczekiwanej użyteczności ani w ogóle żadnej zaawansowanej wiedzy. 
Jednak u rzeczywistych decydentów „paradoks Allais” - nieracjonalny wybór decyzji A w pierwszej parze i D w drugiej - jest w znacznym stopniu odporny nawet na tę argumentację. Pokazali to Paul Slovic i Amos Tversky (1974), którzy przedstawili grupie studentów zarówno werbalną argumentację Allaisa za wyborem A i D, jak i tabelę 3 Savage'a, i zaobserwowali 35\% wybierających A i D. To i inne systematyczne odchylenia od standardowej racjonalności dały mocny impuls do rozwoju ekonomii behawioralnej, badającej te zjawiska i tworzącej alternatywne teorie postępowania ekonomicznego.

Wydaje się, że w 2021 roku, kiedy powstał ten tekst, można spojrzeć na wynik Allaisa trochę inaczej niż w połowie XX wieku. Ani dzisiaj, ani wtedy żaden decydent nie dokonywał tak naprawdę obliczeń oczekiwanej użyteczności. Pojęcie funkcji użyteczności było i pozostaje nieznane nabywcom, sprzedawcom i menedżerom, ludziom, którzy mają dużo czasu i się spieszą, oraz ludziom, którzy potrafią i nie potrafią prowadzić obliczenia. Dlatego wiele elementów normatywnej teorii podejmowania decyzji ma znaczenie w dużym stopniu dydaktyczne: porządkują myślenie decydentów i uświadamiają im, na co powinni zwracać uwagę. W praktyce będą oni działać bez formalnych schematów.

W dzisiejszych czasach sytuacja uległa pewnej zmianie: proste aplikacje instalowane do przenośnych urządzeń elektronicznych pozwalają wyznaczyć oczekiwaną użyteczność w jedną chwilę. Kłopotu technicznego, który występował w czasach Allaisa, nie ma. Takich obliczeń nie robi się zapewne przede wszystkim dlatego, że decydenci na ogół nie wiedzą, czym jest oczekiwana użyteczność i inne podobne do niej pojęcia. Jeżeli uwaga ta jest słuszna, podnosi to znaczenie paradoksu Allais i osłabia praktyczne znaczenie podejścia normatywnego. Myślimy i decydujemy bardziej nieformalnie niż formalnie.

Waży na tym jeszcze jedno poważne ograniczenie, którego obecny rozwój technik obliczeniowych nie jest w stanie znacząco osłabić. Rzeczywiste decyzje częściej są podejmowane w warunkach niepewności niż w warunkach ryzyka, a więc bez znajomości rzeczywistego rozkładu prawdopodobieństwa. W wielu przypadkach można szacować go na podstawie danych z przeszłości, ale zawsze będzie to budzić kontrowersje. Jest to także czynność dość skomplikowana - nie wystarczy do niej prosta aplikacja w smartfonie w ręku decydenta.

Maurice Allais był absolwentem École Polytechnique i dyrektorem Conseil d'Analyse Economique w École Nationale Supérieure des Mines de Paris. Wśród jego uczniów znaleźli się Gérard Debreu, pracujący w USA noblista z 1983 roku, oraz głośny ekonomista znany z zastosowań matematyki Edmond C. Malinvaud. Allais początkowo zajmował się fizyką i techniką, zainteresowania ekonomiczne rozwinął podczas podróży do USA w okresie wielkiego kryzysu. 
Jak już powiedzieliśmy, w ekonomii interesowało go nie tylko podejmowanie decyzji. Badał on warunki efektywnego wykorzystywania zasobów w dużych przedsiębiorstwach publicznych o pozycji monopolistycznej. Stał się znany z prac w zakresie równowagi ogólnej w gospodarce. Zaliczany jest do głównych twórców tak zwanej syntezy neoklasycznej, dość powszechnie akceptowanej teorii opierającej niektóre elementy teorii Keynesa na fundamentach klasycznej mikroekonomii. Sformułował złotą regułę akumulacji: maksymalizacja realnego dochodu wymaga, by stopa procentowa była równa zeru lub była równa aktualnej stopie wzrostu. Opowiadał się za liberalizacją handlu międzynarodowego i integracją europejską. Swe poparcie łączył ze wskazywaniem ujemnych stron tych procesów ekonomicznych. Uważał, że na krótką metę eliminacja barier dla handlu zagranicznego przynosi więcej korzyści krajom wysoko rozwiniętym, jednak w dłuższym okresie rozkład korzyści zmienia się, więcej na niej zyskują kraje biedniejsze. Zajmował się także problemem podaży pieniądza, co dało mu miejsce wśród pionierów analiz monetarnych. Do szerokiego obiegu weszło wygłoszone przez niego zdanie: im mniejsze jest ryzyko, tym bardziej uciekają spekulanci. Publikował prace z zakresu badań operacyjnych. Pisał po francusku $^{2}$, co w ocenie jednego z najważniejszych ekonomistów XX wieku, Paula Samuelsona (1915-2009), ograniczyło znajomość jego dokonań na świecie i opóźniło przyznanie mu Nagrody Nobla.

W 1947 roku był uczestnikiem posiedzenia inauguracyjnego Mont Pèlerin Society, wpływowej organizacji myślicieli o nastawieniu liberalnym. Jako jedyny nie podpisał wypracowanej wtedy deklaracji celów. Powodem było sprawa własności kapitału. Jego zdaniem efektywne mogą być zarówno rozwiązania prywatne i kolektywne, o ile tylko gospodarka jako całość funkcjonuje na zasadach rynkowych. W 1959 roku włączył się w działalność Mouvement pour une société libre, promującej liberalizm socjalny, różny od leseferyzmu i od tradycyjnego socjalizmu.

Niewątpliwie był ekonomistą „renesansowym”.

2 M. Allais, A la recherche d'une discipline economique (1943), Économie et intérêt (1947), La question des houilleres nationalisees et la theorie economique (1953), Les theories de l'equilibre general et de l'efficacite maximale (1971), La liberasation des relations economiques internationales (1972), La Théorie générale des surplus et l'économie de marchés (1990), La Mondialisation, la destruction des emplois et de la croissance, l'évidence empirique (2007). 


\section{Bibliografia}

Allais, M. (1943). A la recherche d'une discipline economique, Ateliers Industria.

Allais, M. (1947). Économie et intérêt, Imprimerie Nationale et Librairie des publications Officielles, Paris

Allais, M. (1953). Le comportement de l'homme rationnel devant le risque: critique des postulats et axiomes de l'école Américaine. Econometrica, 21, 503-546.

Allais, M. (1953). La Gestion des Houillères Nationalisées et la Théorie Économique, Imprimerie Nationale, Paris.

Allais, M. (1971). La Libéralisation des Relations Économiques Internationales, Gauthier-Villars.

Allais, M. (1990). La Théorie générale des surplus et l'économie de marchés.

Allais, M. (1999). La Mondialisation. La Destruction des Emplois et de la Croissance. L' Évidence Empirique. Éditions Clément Juglar.

Jasiński, L.J. (2021). Nobliści z ekonomii 1969-2020, Warszawa: Key Text.

MacCrimmon, K.R. (1968). Descriptive and normative implications of the decision-theory postulates. W: Borch K., Mossin J., Risk and Uncertainty, London: Palgrave Macmillan.

Savage, L.J. (1954). The Foundations of Statistics. New York: Wiley.

Slovic, P., Tversky, A. (1974). Who Accepts Savage's Axiom?, Behavioral Science, 19, 368-373.

Teitelbaum, J., Zeiler, K. (red.) (2018). Research Handbook on Behavioral Law and Economics, Northampton: Edward Elgar.

Tyszka, T. (2010). Decyzje. Perspektywa psychologiczna i ekonomiczna. Warszawa: Scholar.

Tyszka, T., Zaleśkiewicz, T. (2001). Racjonalność decyzji. Warszawa: PWE. 